\title{
THE IMPACT OF KNOWLEDGE RISK ON SUSTAINABILITY OF FIRMS
}

\author{
Constantin Brătianu ${ }^{*}$, Andrei Ștefan Neștian², Silviu Mihail Tițăă \\ Ana Iolanda Vodă ${ }^{4}$ and Alexandra Luciana Guță \\ 1) University of Economic Studies, Bucharest, Romania \\ ${ }^{233445)}$ Alexandru Ioan Cuza University, Iași, Romania
}

Please cite this article as:

Brătianu, C., Neștian, A.Ș, Tiță, S.M., Vodă, A.I. and Guță, A.L., 2020. The Impact of Knowledge Risk on Sustainability of Firms. Amfiteatru Economic, 22(55),

Article History

Received: 25 March 2020

Revised: 29 April 2020

Accepted: 25 May 2020 pp. 639-652.

DOI: $10.24818 / \mathrm{EA} / 2020 / 55 / 639$

\begin{abstract}
The purpose of this paper is to investigate the impact of knowledge risk on the business sustainability of firms. In the knowledge economy, knowledge is a strategic resource of any firm, and it contributes significantly to the organizational performance and its competitive advantage. Knowledge risk is generated by knowledge absence, loss, leakage, spillover, and any other activity that induces uncertainty in decision-making. The present research focuses on the linkage between knowledge risk management and the firms' sustainability, having organizational performance as a mediating factor between knowledge risk and sustainability, and decision-making as a moderating factor between organizational performance and sustainability. The research integrates the qualitative approach based mostly on a critical analysis of the literature, and the quantitative approach based on designing a structural equation model and an associated questionnaire distributed online to a number of 1500 respondents from the business environment. Data obtained from the 299 valid questionnaires was processed by using STATA as a specialized program for statistical analysis and by using Structural Equation Modeling. The results confirm the structure of the research model and its associated hypotheses. Knowledge risk impacts firms' sustainability through the moderation of organizational performance. Decision-making impacts organizational performance and sustainability such that it acts as a moderating factor of the linkage between these constructs.
\end{abstract}

Keywords: knowledge risk, sustainability, organizational performance, decision-making, risk management, knowledge management.

JEL Classification: C83, D83, Q01.

* Corresponding author, Constantin Brătianu - constantin.bratianu@ gmail.com 


\section{Introduction}

Knowledge risk is an emergent construct in knowledge management that is related to risk management and decision-making in conditions of uncertainty (Durst and Zieba, 2017; Massingham, 2010; Sumbal et al., 2018; Zieba and Durst, 2018). Knowledge risk represents the risk of generating perturbations in the organizational knowledge field (Brătianu and Bejinaru, 2019) such that organizational output in products and services cannot reach the expected level of performance. Knowledge risk can be defined as being "the measure of the probability and severity of adverse effects of any activities engaging or related somehow to the knowledge that can affect the functioning of an organization on any level" (Zieba and Durst, 2018, p. 256).

The main distinction from the classical risk management comes from the fact that instead of dealing with events related to tangible resources of firms, knowledge risk management is dealing with intangible resources and the firms' intellectual capital, which makes the whole approach much more difficult (Brătianu, 2018a; Davenport and Prusak, 2000; North and Kumta, 2018). Knowledge risk implies potential events with negative consequences upon the firm's operational performance, but once they do happen, these consequences may affect the competitive advantage of the firm severely. Because knowledge is a strategic resource (Nonaka, Toyama and Hirata, 2008), the knowledge risk impacts the future business of the firm and its sustainability. The importance of business sustainability was brought forward first by the Brundtland Report (WCED, 1987), and then supported by many research projects. Today, sustainability is conceived in its triple bottom line perspective focusing equally on economic, social, and environmental dimensions (Goyal, Rahman and Kazmi, 2013; Labuschagne, Brent and Van Erck, 2005). In the present research, we shall consider sustainability from the perspective of "adopting business strategies and activities that meet the needs of the enterprise and its stakeholders today while protecting, sustaining and enhancing the human and natural resources that will be needed in the future" (Elkigton, 1998, p. 362).

The focus of the present research is on the linkage between knowledge risk and sustainability through the mediating role of organizational performance, and the moderating role of decision-making between organizational performance and sustainability. The structural equation model (Hair et al., 2017) supported our questionnaire design, and the specialized software STATA helped us in statistical processing of collected data from respondents from the business environment. The results validated our hypotheses and the structural research model. The structure of the present paper is as follows: introduction, literature review, methodology, results and discussions, conclusions and references.

\section{Literature review}

The concept of risk is always associated with potential danger, and risk management with the rational activity of finding solutions for reducing the likelihood of that potential danger, and measures for mitigating it in case of happening (Bernstein, 1998). Knowledge risk is focused on the organizational knowledge and the potential events of the absence of needed knowledge, losing knowledge, or using it in an adverse way (Durst and Wilhelm, 2011, 2013; Kim and Park, 2017; Massingham, 2008, 2010). The key idea related to risk is that of decision-making in conditions of uncertainty. The concept of uncertainty integrates the objective and subjective aspects of knowledge and their dynamics (Knight, 2006; Lindley, 
2006; Spender, 2014). “According to objective interpretations, probabilities are real. We may discover them by logic or estimate them through statistical analyses. According to subjective interpretations, probabilities are human beliefs. They are not intrinsic to nature. Individuals specify them to characterize their uncertainty" (Holton, 2004, p. 19). This dynamics between subjective and objective knowledge reflects the dynamics between emotional and rational knowledge (Brătianu and Bejinaru, 2020) and the way our brain works switching between system 1 and system 2 of thinking (Damasio, 2012; Kahneman, 2011). Uncertainty is generated by the absence of some information and knowledge, as well as our state of knowing within a certain domain. It influences strongly the managerial decision-making as a result of assuming some potential risks (Colemann and Casselman, 2016; Knight, 2006; Lindley, 2006).

Amongst several types of knowledge risks, the most important and the most researched one is knowledge loss (Brătianu, 2018b; Massingham, 2008). Knowledge loss manifests when a significant number of employees retire almost simultaneously or in a given short period of time. They leave the firm with their experience and expertise, which might happen to represent critical knowledge and to impact the knowledge equilibrium negatively within the organization (Brătianu, Agapie and Orzea, 2011; DeLong, 2004; Jennex, 2014; Joe, Yoong and Patel, 2013). A classic example of knowledge loss risk is what happened at NASA after the first successful Apollo missions when many experienced scientists and engineers were stimulated to accept an early retirement program, and the whole organization suffered a critical knowledge loss (DeLong, 2004; Mahler and Casamayou, 2009). Mitigating such a risk can be accomplished by intergenerational learning, mentoring, and knowledge retention strategies (Brătianu, 2014).

Knowledge risk has a strong impact on organizational performance as a result of the potential danger for losing critical knowledge, reducing innovation capability, and departing from the state of competitive advantage (Aven, 2016; Durst, Hinteregger and Zieba, 2019; Swart and Harvey, 2011). Here, organizational performance refers to its capacity for attaining the proposed objectives and the level of employees' satisfaction that is necessary for a sustainable innovation process. Thus, organizational performance integrates rational, emotional, and spiritual aspects along the line of sustainability (Gelhard and von Delft, 2016). The linkage between organizational performance and sustainability is moderated by decision-making and strategic thinking. Because knowledge is a strategic resource, all the knowledge strategies incorporate in their dynamics knowledge risks, and measures to mitigate the effects of adverse consequences. It is important to understand that sustainability is a concept that goes beyond the linear economic theory focused on profit maximization, and incorporates values that guide the process of decision-making. Thus, the construct of decision-making in our structural model appears as a moderating factor of the linkage between organizational performance and sustainability.

\section{Research methodology}

\subsection{The research model}

The present research integrates qualitative and quantitative thinking models and analysis methods (Bryman and Bell, 2007; Jankowicz, 2005). The qualitative research is based on a critical analysis of the literature concerning the influence of knowledge risk on sustainability and on the identification of the major constructs which are linked with the 
knowledge risk in the organizational system of the firm. As described in the literature review, the major constructs in our view are knowledge risk, organizational performance, decision-making, and sustainability. The input construct of our analysis is knowledge risk, and our question is related to its potential to impact the firm's sustainability, through the mediating effect of organizational performance. However, organizational performance depends on the managerial decision-making, and thus, the construct of decision-making appears as a moderating factor with respect to organizational performance and sustainability. Organizational performance impacts on the firm's sustainability, and becomes a mediating factor between the knowledge risk and the firm's sustainability.

To explore the causal relationships between these four major constructs, we design a research model based on the theory of structural equation modeling (Hair et al., 2017). A conceptual path diagram of the structural model is presented below (figure no. 1). The arrows represent the directions of the hypothesized influences in the structural model. The research is based on the following hypotheses:

- Hypothesis 1 (H1) - Knowledge risk has a negative influence on organizational performance.

- Hypothesis $2(\mathrm{H} 2)$ - Decision-making has a positive influence on organizational performance.

- Hypothesis 3 (H3) - Decision-making has a positive and significant influence on sustainability.

- Hypothesis $4(\mathrm{H} 4)$ - Organizational performance has a positive influence on sustainability.

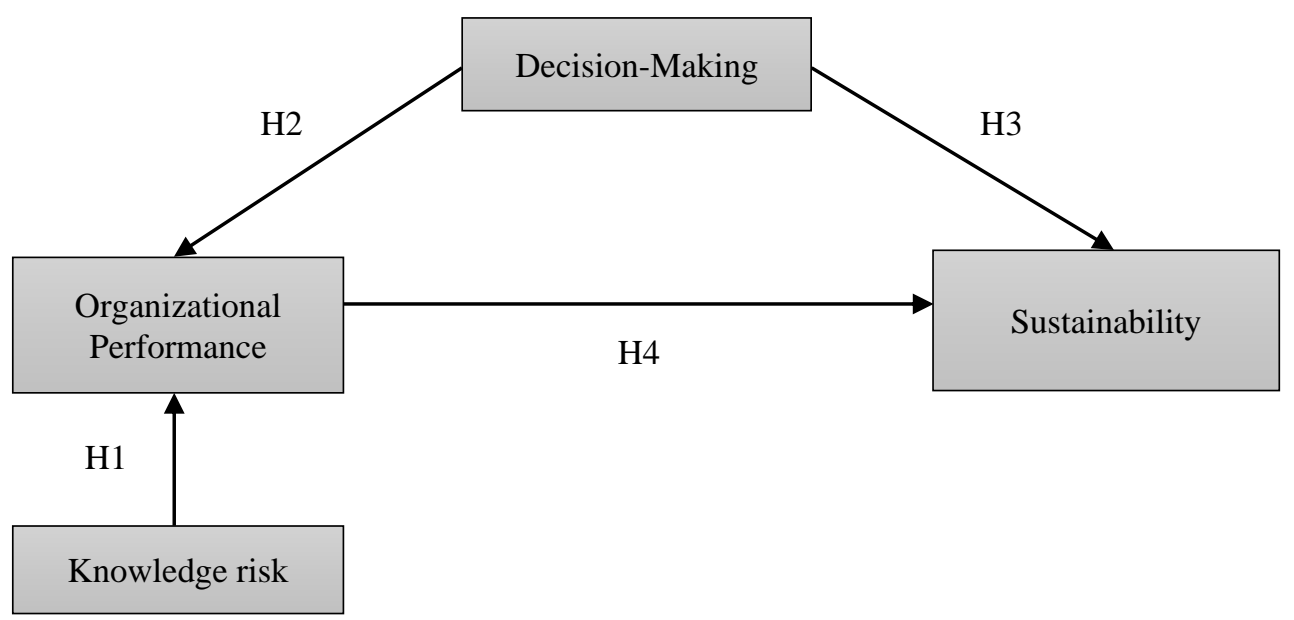

Figure no. 1. The theoretical research model

\subsection{Designing the survey}

The survey method was adopted to test the hypotheses proposed in this study. Data were analyzed by using a SEM (Structural Equation Modeling) software package. This statistical technique was used to analyze the inter-relationships between different constructs, taking into consideration potential moderating and mediating effects. The use of this particular 
analysis is justified as of its ability to model latent variables, correct and specify measurement errors, and their covariance structure. STATA software program was used to interpret and assess the causal influences of the constructs. Multiple indicators were used to evaluate the fit of the model, including Comparative Fit Index (CFI), Tucker-Lewis Index (TLI), Standardised root mean squared residual (SRMR) and Coefficient of determination (CD).

The survey questionnaire was divided into three sections. In the first section of the questionnaire a brief introduction on the topic, as well as the main objective of the research, have been provided. The second section captures different aspects of our research, including the four main constructs. The last part of the survey captured the basic profile of respondents, including their gender, education level, experience, net income, and organization size. The four constructs and the items which describe them in the questionnaire are presented in the first table (table no. 1).

Table no. 1. Constructs and items

\begin{tabular}{|c|c|}
\hline Co. & Items \\
\hline \multirow{7}{*}{ KR } & $\begin{array}{l}\text { KR1: The leave from the firm od some specialists and experts in a business } \\
\text { domain can lead to losses of unique technical knowledge and competences for the } \\
\text { organization. }\end{array}$ \\
\hline & $\begin{array}{l}\text { KR2: The leave from the firm of a colleague with experience can negatively } \\
\text { influence the working climate of the team where he was working. }\end{array}$ \\
\hline & $\begin{array}{l}\text { KR3: The leave from the firm of an old member of a team can produce a negative } \\
\text { emotion for a long time. }\end{array}$ \\
\hline & $\begin{array}{l}\text { KR4: The leave from the firm of an old member of a team can influence the } \\
\text { working spirituality of the team negatively. }\end{array}$ \\
\hline & $\begin{array}{l}\text { KR5: The leave from the firm of employees with long working experience in it } \\
\text { can lead to losing some valuable references for the younger employees. }\end{array}$ \\
\hline & $\begin{array}{l}\text { KR6: The leave from the firm of employees with long working experience in it } \\
\text { can lead to generating some ambiguities for the younger employees in } \\
\text { understanding the meaning of their work. }\end{array}$ \\
\hline & References: Brătianu, 2018b; Durst and Wilhelm, 2013; Massingham, 2010 \\
\hline \multirow{10}{*}{$\mathrm{OP}$} & $\begin{array}{l}\text { OP1: The firm deployed its resources efficiently (human, financial, material, and } \\
\text { informational). }\end{array}$ \\
\hline & OP2: The firm achieves its defined performance objectives. \\
\hline & OP3: Employees are happy to work in this firm. \\
\hline & OP4: The firm meets its customers' needs. \\
\hline & $\begin{array}{l}\text { OP5: The firm assures the necessary conditions for improving future } \\
\text { performance. }\end{array}$ \\
\hline & OP6: The firm has a strategy that positions it well for the future. \\
\hline & OP7: The firm improves its activity continuously. \\
\hline & OP8: The firm invests in creating new products and services. \\
\hline & OP9: The firm focuses on the quality of the offered products and services. \\
\hline & $\begin{array}{l}\text { References: Bontis, Crossan and Hulland, 2002; Jyothibabu, Farooq and } \\
\text { Pradhan, 2010; Guță, 2014; Jennex, } 2014\end{array}$ \\
\hline
\end{tabular}




\begin{tabular}{|c|c|}
\hline \multirow{3}{*}{$\mathrm{DM}$} & $\begin{array}{l}\text { DM1: The best decisions made by managers depend on the shared principles } \\
\text { within the firm. }\end{array}$ \\
\hline & $\begin{array}{l}\text { DM2: Sharing the same values by employees in the organization contributes to } \\
\text { solving problems within teams. }\end{array}$ \\
\hline & References: Kahneman, 2011 \\
\hline \multirow{7}{*}{ SUS } & $\begin{array}{l}\text { S1: With all its activities and processes, the firm is concerned with the protection } \\
\text { of the natural environment. }\end{array}$ \\
\hline & S2: Your firm is concerned with the needs and welfare of the community. \\
\hline & S3: Your firm is concerned with the reduction of energy consumption. \\
\hline & $\begin{array}{l}\text { S4: Your firm is concerned with the reduction of using natural non-regenerative } \\
\text { resources. }\end{array}$ \\
\hline & S5: Your firm is concerned with the alleviation of poverty in its community. \\
\hline & $\begin{array}{l}\text { S6: Your firm is concerned with promoting a healthy life model both inside and } \\
\text { outside of it. }\end{array}$ \\
\hline & References: Gelhard and von Delft, 2016 \\
\hline
\end{tabular}

Knowledge risk $(K R)$ assessment consists of six items measured using a five-point Likert scale ranging from one (strongly disagree) to five (strongly agree) (Brătianu, 2018b; Durst and Willhelm, 2013; Massingham, 2010). The respondents have to answer the questions KR1-KR6, as presented in table no. 1. Organizational performance $(O P)$ consists of nine items, with answers evaluated on a five-point Likert scale ( $1=$ strongly disagree, $2=$ disagree, $3=$ neutral, 4=agree, and $5=$ strongly agree). High score values indicate increased organizational performance, and low values the opposite. We started from a previously tested and validated scale developed by Jyothibabu, Farooq and Pradhan (2010) based on a scale proposed by Bontis, Crossan and Hulland (2002) and used with minor modifications by Guță (2014) and Jennex (2014), which has been adapted in order to integrate it in the analysis: three additional items were added as a measurement for organizational performance, and some of the questions were modified in order to highlight more clearly different aspects of the research; one item from Jyothibabu, Farooq and Pradhan (2010) was not been taken into consideration in the questionnaire. For the scale measuring organizational performance we adopted impersonal formulations of the items, as used in Guță (2014) and we have reformulated some of the items. For decision-making (DM) we take into consideration 2 items, which were measured using a five-point Likert scale ranging from one (strongly disagree) to five (strongly agree). The respondents were asked to indicate if the best decisions made by managers depend on the shared principles within the firm and if sharing the same values by employees in the organization contributes to solving problems within teams (Kahneman, 2011). Sustainability (SUS) consists of six items, measured using a five-point Likert scale ranging from one (strongly disagree) to five (strongly agree), where higher score values indicate higher levels associated with sustainability (Gelhard and von Delft, 2016).

\subsection{Data and sample}

First, we developed one pilot study which was conducted in order to evaluate the reliability of the constructs. The pilot study was sent to a small size sample for completion, a number estimated at 20 respondents. Different reliability tests were used to validate the constructs and to identify deficient and promising items. The final version of the survey was developed and, by using online platforms, the questions were distributed to potential respondents from the business environment, from January 2020 to February 2020. We 
randomly selected 1500 respondents, out of which only 320 were willing to participate in the survey. In the final analysis, we included a total number of 299 valid responses. The percentage of valid responses was $19.93 \%$. In order to assure the anonymity of the respondents, any personal identification data have not been collected. In order to reach as many people as possible, we used direct messaging via classic email services and via different social platforms: LinkedIn and Facebook.

The vast majority of the respondents are females (64.88\%), and only a small percentage are males (35.12\%). The respondents' education level is grouped into four categories: secondary education (1\%), B.Sc. (24.75\%), M.Sc. (67. 56\%) and Ph.D. (6.69\%). The structure of the sample, with $99 \%$ of the respondents having at least higher education and $74.25 \%$ having post-graduate education (master or Ph.D.), positions the majority of the respondents in the category of knowledge workers, able to understand the value of knowledge and the consequences of decision making on the firm's performance and sustainability. (table no. 2)

Table no. 2. Distribution for the research sample $(n=299)$

\begin{tabular}{|c|c|c|c|}
\hline Variable & Frequency & Percent & Cumulative Percent \\
\hline \multicolumn{4}{|l|}{ Gender distribution } \\
\hline Female & 194 & 64.88 & 64.88 \\
\hline Male & 105 & 35.12 & 100.00 \\
\hline Total & 299 & 100.00 & \\
\hline \multicolumn{4}{|l|}{ Educational level } \\
\hline Secondary education & 3 & 1.00 & 1.00 \\
\hline Bachelor's degree & 74 & 24.75 & 25.75 \\
\hline Master degree & 202 & 67.56 & 93.31 \\
\hline $\mathrm{PhD}$ & 20 & 6.69 & 100.00 \\
\hline Total & 299 & 100.00 & \\
\hline \multicolumn{4}{|c|}{ Number of employee's within the organization } \\
\hline$<10$ employee & 51 & 17.06 & 17.06 \\
\hline 10-49 employees & 63 & 21.07 & 38.13 \\
\hline 50-249 employees & 55 & 18.39 & 56.52 \\
\hline 250 or over & 130 & 43.48 & 100.00 \\
\hline Total & 299 & 100.00 & \\
\hline \multicolumn{4}{|l|}{ Age } \\
\hline$<25$ year old & 49 & 16.39 & \\
\hline $26-35$ & 166 & 55.52 & \\
\hline $36-45$ & 67 & 22.41 & \\
\hline Over 46 & 17 & 5.68 & \\
\hline Total & 299 & 100.00 & \\
\hline \multicolumn{4}{|l|}{ Net salary (RON) } \\
\hline Not answering & 45 & 15.05 & 15.05 \\
\hline$<1500$ & 5 & 1.67 & 16.72 \\
\hline 1500-2999 & 74 & 24.75 & 41.47 \\
\hline $3000-4499$ & 73 & 24.41 & 65.89 \\
\hline$>4500$ & 102 & 34.11 & 100.00 \\
\hline Total & 299 & 100.00 & \\
\hline
\end{tabular}


A major part of the respondents work in large companies with 250 employees or more (43.48\%), $18.38 \%$ in enterprises with 50 to 249 employees, $21.07 \%$ work in firms with 10 to 49 employees and only a small percentage work in microenterprises with less than 10 employees $(17.06 \%)$. More than half of respondents earn more than the average net salary, while $24.75 \%$ of the respondents earn a net income between 1500 and 2999 RON and $1.67 \%$ earn under $1500 \mathrm{RON}$. The sample distribution shows that $16.39 \%$ of the respondents are 25 or fewer years old, $55.52 \%$ are aged between 26 and 35 years old, and $28.09 \%$ of respondents are 36 years old or above (table no. 2)

\section{Results and discussions}

The table below shows the descriptive statistics (mean and standard deviation) of the variables included in the study. Evidence shows that the mean score for sustainability components range from $\mathrm{M}=2.993$ to $\mathrm{M}=3.729$; for organizational performance from $\mathrm{M}=3.612$ to $\mathrm{M}=4.260$. For decision making, the mean score range between $\mathrm{M}=3.856$ to $\mathrm{M}=4.317$, while for the items assessing knowledge risk, the values range between $\mathrm{M}=3.023$ to $\mathrm{M}=4.075$ (table no. 3 ).

Table no. 3. Descriptive statistics of the variables used in the structural equation modeling $(\mathrm{SEM})(\mathrm{n}=\mathbf{2 9 9})$

\begin{tabular}{|c|c|c|c|c|c|c|c|}
\hline & Items & Mean & SD & & Items & Mean & SD \\
\hline \multirow{9}{*}{$K R$} & KR_1 & 4.075 & 0.660 & \multirow{9}{*}{$O P$} & OP1 & 3.612 & 0.964 \\
\hline & KR_2 & 3.581 & 1.017 & & OP2 & 3.906 & 0.850 \\
\hline & KR_3 & 3.337 & 1.063 & & OP3 & 3.645 & 0.927 \\
\hline & KR_4 & 3.541 & 0.997 & & OP4 & 4.110 & 0.784 \\
\hline & KR_5 & 3.023 & 1.124 & & OP5 & 3.745 & 1.017 \\
\hline & KR_6 & 3.093 & 1.148 & & OP6 & 3.779 & 1.070 \\
\hline & & & & & OP7 & 3.969 & 0.967 \\
\hline & & & & & OP8 & 3.909 & 1.010 \\
\hline & & & & & OP9 & 4.260 & 0.926 \\
\hline \multirow[t]{6}{*}{$D M$} & DM_1 & 3.856 & 0.883 & \multirow[t]{6}{*}{$S U S$} & S1 & 3.675 & 1.116 \\
\hline & DM_2 & 4.317 & 0.804 & & S2 & 3.729 & 1.076 \\
\hline & & & & & S3 & 3.254 & 1.243 \\
\hline & & & & & S4 & 3.190 & 1.206 \\
\hline & & & & & S5 & 2.993 & 1.204 \\
\hline & & & & & S6 & 3.411 & 1.229 \\
\hline
\end{tabular}

Note: $S D=$ Standard Deviation

Cronbach's alpha remains the most common measure for estimating the internal consistency reliability of the constructs, which requires only a single test administration to provide a unique estimate of the reliability for a given test. In this study, the alpha values for Sustainability (0.898), Organizational Performance (0.933), and Knowledge Risk (0.849) are above 0.8 , which indicates reliable solutions for our constructs. For Decision-Making 
(DM) the value is situated between 0.6 and 0.7 , a solution considered acceptable for exploratory analysis and given the relatively small number of respondents within our sample (Hair et al., 2017; Nunnally and Bernstein, 1994) (table no. 4).

Table no. 4. Reliability statistics

\begin{tabular}{|l|c|c|c|}
\hline & Scale & Cronbach Alpha & No. of items \\
\hline Sustainability $(S U S)$ & $1-5$ & 0.898 & 6 \\
\hline Organizational Performance $(O P)$ & $1-5$ & 0.933 & 9 \\
\hline Knowledge Risk $(K R)$ & $1-5$ & 0.849 & 6 \\
\hline Decision-Making $(D M)$ & $1-5$ & 0.655 & 2 \\
\hline
\end{tabular}

The figure below presents the resulted structural model (figure no. 2).

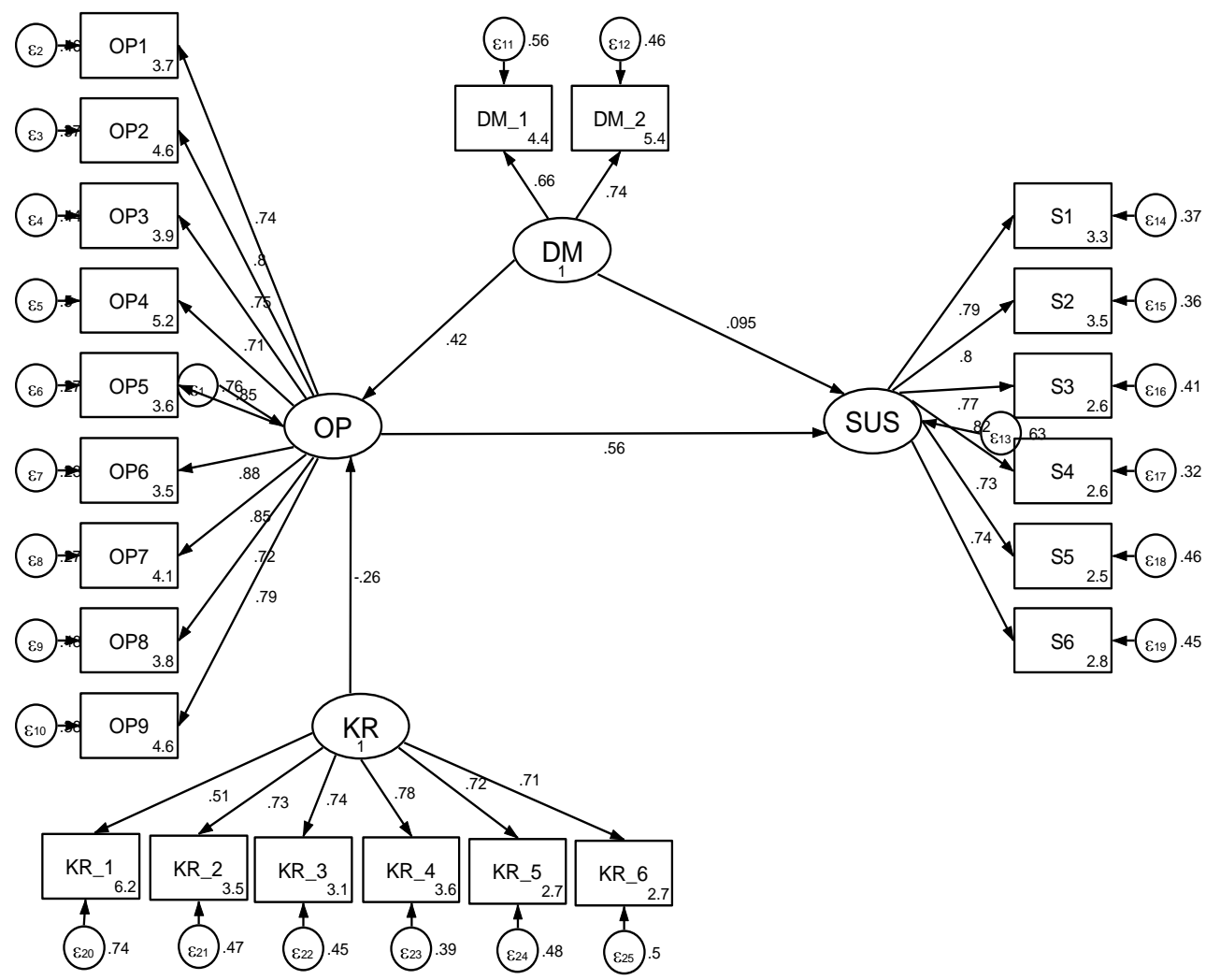

Figure no. 2. The structural model

The inner structural model assessment helps to investigate the empirical data to confirm the underlying theory. Table no. 5 presents the developed hypotheses, the path, coefficients, the standard errors, and the significance of the relationships (table no. 5). H1 hypothesized that knowledge risk has a negative influence on organizational performance. The findings confirm the significant relationship $(\beta=-0.264 ; \mathrm{p}=0.000)$. Therefore, H1 is supported. Decision-making has a positive influence on organizational performance was hypothesized in H2. The results support the hypothesis validation $(\beta=0.420 ; p=0.000)$. Decision-making 
was also predicted to positively influence sustainability $(\beta=0.094 ; p=0.178)$. The results indicate that hypothesis $\mathrm{H} 3$ is partially accepted. The relationship between buildings is a positive but insignificant one as the associated risk is $20 \%$. Furthermore, H4 hypothesized that organizational performance has a positive influence on sustainability. The results $(\beta=0.559 ; \mathrm{p}=0.000)$ provides empirical support to validate H4. (table no. 5)

Table no. 5. SEM output

\begin{tabular}{|c|c|c|c|c|c|}
\hline Hypothesis & Relation & $\begin{array}{c}\text { Coeff. of } \\
\text { regression ( } \beta)\end{array}$ & SD & Sig. & Result \\
\hline H1 & OP <-KR & -0.264 & 0.057 & 0.000 & Validated \\
\hline H2 & OP <-DM & 0.420 & 0.062 & 0.000 & Validated \\
\hline H3 & SUS <-DM & 0.094 & 0.069 & 0.178 & Partially Validated \\
\hline H4 & SUS <-OP & 0.559 & 0.053 & 0.000 & Validated \\
\hline
\end{tabular}

According to the specialized literature the most common tests recommended to validate the model include: Comparative Fit Index (CFI) with the value ranging from 0 (no fit) and 1 (perfect fit), Tucker-Lewis Index TLI is 0 (no fit) and 1(perfect fit), Standardised root mean squared residual (SRMR), and Coefficient of determination (CD) (Hair et al., 2009). $\mathrm{CFI}=0.978$ and $\mathrm{TLI}=0.964$, two indices with values close to 1 , indicate a good fit for our model. A perfect fit corresponds to a SRMR of 0 , and a good fit corresponds to a small value, considered by some to be limited at 0.08 . Our model fits well with the standard, with a $S R M R=0.064$. In our model, $C D=0.960$ a value close to 1 , which indicates a good fit.

The validity of Hypothesis 1 contributes to the idea that manifestation of knowledge risks has a negative influence on organizational performance, since the unavailability of the necessary knowledge triggers multiple negative consequences for the organizational performance, affecting it on a broad spectrum: the quality of products and services, the efficient use of its available resources, meeting the needs of customers, ensuring the conditions for future performance growth, investments in the launch of new products / services on the market. When a senior expert or an experienced member of a team leaves the company, the organizational performance is hindered by direct effects generated on the actual work by the lost skills and technical knowledge, but also by the effects on the organizational culture, on the work climate and on the general emotional state, turned into a negative one.

Our model also shows that organizational performance is a mediator between knowledge risks and organizational sustainability. Based on the validation of Hypothesis 4 we can state that organizational performance has a positive influence on sustainability. Hence, knowledge risks have an influence on the sustainability of the organization, but this influence is not direct. It is mediated by the level of organizational performance.

The validity of Hypothesis 2 and partially of 3 leads to the conclusion that decision-making has a positive influence both on organizational performance and on the organizational sustainability, acting as a moderating factor of the linkage between these constructs. Decision making contains a part referring to respecting the principles in the organization and a part about sharing the same values when making decisions in solving problems within teams. As a moderator variable, decision making influences the strength of the relationship between the two other variables: organizational performance and sustainability of the organization. 


\section{Conclusions}

In the knowledge economy, knowledge risk represents a major factor in achieving organizational performance and impacting the firm's sustainability. Knowledge risk manifests in several forms, but the most important is knowledge loss that is generated by people who retire or just leave the firm. They leave with their tacit knowledge, experience, and expertise, which may be critical for the firm's performance and its sustainability. The present research focuses on the impact of knowledge risk upon the firm's sustainability, having organizational performance as a mediating factor and decision-making as a moderating one. The research is designed as an integrated approach between the qualitative and quantitative components. The qualitative part resulted in a research model composed of the four constructs (i.e., knowledge risk, organizational performance, decision-making, and sustainability), and the links between them. These links suggest the research hypotheses considered and the objective of the quantitative approach through a survey based on a questionnaire. The statistical data is analyzed by using STATA, and they confirm the validity of the structural model and the proposed hypotheses. Knowledge risk impacts the organizational performance of the firm and that performance influences significantly the firm's sustainability. Organizational performance acts as a mediating construct, and the decision-making as a moderating one. Knowledge risk management should concentrate on operational ways of reducing the probability of a significant knowledge loss and of mitigating its negative consequences on the organizational performance and sustainability.

The present research focused only on knowledge loss as the major component of the knowledge risk. That is a limitation, and future research should include some other forms of knowledge risk like knowledge leakage, knowledge hiding and hoarding. Also, the sample for quantitative research can be increased to improve the statistical causality significance.

Future research should also generalize the validity of the model on an international scale, taking into consideration the potential moderating effects of cultural differences between countries. In addition, it will be desirable to carry out a longitudinal study which will provide a more in depth analysis on the topic and might contribute to reducing the probability of significant knowledge losses and of mitigating their negative consequences.

\section{References}

Aven, T., 2016. Risk assessment and risk management: Review of recent advances on their foundation. European Journal of Operational Research, [e-journal] 253, pp.1-13. https://doi.org/10.1016/j.ejor.2015.12.023.

Bernstein, P.L., 1998. Against the Gods: The remarkable story of risk. New York, N.Y.: John Wiley \& Sons.

Bontis, N., Crossan, M.M. and Hulland, J., 2002. Managing an organizational learning system by aligning stocks and flows. Journal of Management Studies, [e-journal] 39(4), pp.437-469. https://doi.org/10.1111/1467-6486.t01-1-00299.

Brătianu, C., 2014. Strategies to enhance intergenerational learning in universities. In: J. Rooney and V. Murthy, The $11^{\text {th }}$ International Conference on Intellectual Capital, Knowledge Management and Organizational Learning. Sydney, Australia, 6-7 November 2014. Reading: Academic Conferences and Publishing International.

Brătianu, C., 2018a. Intellectual capital research and practice: 7 myths and one golden rule. 
Management \& Marketing. Challenges for the Knowledge Society, [e-journal] 13(2), pp.859-879. https://doi.org/10.2478/mmcks-2018-0010.

Brătianu, C., 2018b. A holistic approach to knowledge risk. Management Dynamics in the Knowledge Economy, [e-journal] 6(4), pp.593-607. https://doi.org/10.25019/ MDKE/6.4.06.

Brătianu, C. and Bejinaru, R., 2019. The theory of knowledge fields: A thermodynamics approach. Systems, [e-journal] 7(2), 20, pp.1-12. https://doi.org/10.3390/ systems 7020020 .

Brătianu, C. and Bejinaru, R., 2020. Knowledge dynamics: A thermodynamics approach. Kybernetes, [e-journal] 49(1), pp.6-21. https://doi.org/10.1108/K-02-2019-0122.

Brătianu, C., Agapie, A. and Orzea, I., 2011. Knowledge dynamics modelling using Analytic Hierarchy Process (AHP). In: G. Turner and C. Minnone, The $3^{\text {rd }}$ European Conference on Intellectual Capital. Nicosia, Cyprus, 18-19 April 2011. Reading: Academic Conferences and Publishing International.

Bryman, A. and Bell, E., 2007. Business research methods. $2^{\text {nd }}$ ed. Oxford, U.K.: Oxford University Press.

Colemann, R. and Casselman, R.M., 2016. Optimizing decisions using knowledge risk strategy. Journal of Knowledge Management, 20(5), pp. 936-958.

Damasio, A.R., 2012. Self comes to mind: Constructing the conscious brain. New York, N.Y.: Vintage Books.

Davenport, T.H. and Prusak, L., 2000. Working knowledge: How organizations manage what they know. Boston, MA: Harvard Business School Press.

DeLong, D.W., 2004. Lost knowledge: Confronting the threat of an aging workforce. Oxford, U.K.: Oxford University Press.

Durst, S., Hinteregger, C. and Zieba, M., 2019. The linkage between knowledge risk management and organizational performance. Journal of Business Research, [e-journal] 105, pp.1-10. https://doi.org/ 10.1016/j.jbusres.2019.08.002.

Durst, S. and Wilhelm, S., 2011. Knowledge management in practice: Insights into a medium-sized enterprise's exposure to knowledge loss. Prometheus, [e-journal] 29(1), pp.23-38. https://doi.org/10.1080/08109028.2011.565693.

Durst, S. and Wilhelm, S., 2013. Do you know your knowledge at risk? Measuring Business Excellence, [e-journal] 17(3), pp.28-39. https://doi.org/10.1108/MBE-082012-0042

Durst, S. and Zieba, M., 2017. Knowledge risks - towards a taxonomy. International Journal of Business Environment, 9(1), pp.51-63.

Elkington, J., 1998. Partnership from cannibals with forks: the triple bottom line of $21^{\text {st }}$ century business. Environmental Quality Management, [e-journal] 8(1), pp.37-51. https://doi.org/10.1002/tqem.3310080106.

Gelhard, C. and von Delft, S., 2016. The role of organizational capabilities in achieving superior sustainability performance. Journal of Business Research, [e-journal] 69, pp.4632-4642. https://doi.org/10.1016/j.jbusres.2016.03.053.

Goyal, P., Rahman, Z. and Kazmi, A.A., 2013. Corporate sustainability performance and firm performance research: Literature review and future research agenda. Management Decision, [e-journal] 51(2), pp.361-379. https://doi.org/10.1108/00251741311301867. 
Guţă, A.L., 2014. Measuring organizational learning. Model testing in two Romanian universities. Management \& Marketing. Challenges for the Knowledge Society, 9(3), pp.253-282.

Hair, J.F.Jr., Hult, G.T.M., Ringle, C.M. and Sarstedt, M., 2017. A primer on partial least squares structural equation modelling (PLS-SEM). 2nd ed. Los Angeles, CA: SAGE.

Hair, J.F., Black, W.C., Babin, B.J. and Anderson, R.E., 2009. Multivariate Data Analysis. 7th ed. New Jersey: Pearson Prentice Hall.

Holton, G.A., 2004. Defining risk. Financial Analysis Journal, [e-journal] 60(6), pp.19-25. https://doi.org/10.2469/faj.v60.n6.2669.

Jankowicz, A.D., 2005. Business research projects. 4th ed. London, U.K.: Thomson.

Jennex, M.E., 2014. A proposed method for assessing knowledge loss risk with departing personnel. VINE Journal of Information and Knowledge Management Systems, [e-journal] 44(2), pp.185-209. https://doi.org/10.1108/VINE-07-2012-0028.

Joe, C., Yoong, P. and Patel, K., 2013. Knowledge loss when older experts leave knowledge-intensive organizations. Journal of Knowledge Management, [e-journal] 17(6), pp.913-927. https://doi.org/10.1108/JKM-04-2013-0137.

Jyothibabu, C., Farooq, A. and Bhusan Pradhan, B., 2010. An integrated scale for measuring an organizational learning system. The Learning Organization, [e-journal] 17(4), pp. 303-327. https://doi.org/10.1108/09696471011043081.

Kahneman, D., 2011. Thinking, fast and slow. New York, N.Y.: Farrar, Strauss and Giroux.

Kim, C.H. and Park, B., 2017. Knowledge spillovers from inward foreign direct investment in the banking industry: An empirical examination in Korea. Management Decision, 55(9), pp. 2053-2072.

Knight, F.H., 2006. Risk, uncertainty and profit. New York, N.Y.: Dover Publications.

Labuschagne, C., Brent, A.C. and Van Erck, R.P., 2005. Assessing the sustainability performance of industries. Journal of Cleaner Production, [e-journal] 13(4), pp.373-385. https://doi.org/10.1016/j.jclepro.2003.10.007.

Lindley, D.V., 2006. Understanding uncertainty. New York, N.Y.: Wiley-Interscience.

Mahler, J.G. and Casamayou, M.H., 2009. Organizational learning at NASA: The Challenger and Columbia accidents. Washington, D.C.: Georgetown University Press.

Massingham, P., 2008. Measuring the impact of knowledge loss: More than ripples on a pond? Management Learning, [e-journal] 39(5), pp.541-560. https://doi.org/10.1177/ 1350507608096040.

Massingham, P., 2010. Knowledge risk management: a framework. Journal of Knowledge Management, [e-journal] 14(3), pp.464-485. https://doi.org/10.1108/13673271011050166.

Nonaka, I., Toyama, R. and Hirata, T., 2008. Managing flow: A process theory of the knowledge-based firm. Houndmills, U.K.: Palgrave Macmillan.

North, K. and Kumta, G., 2018. Knowledge management: Value creation through organizational learning. 2nd ed. Cham, Switzerland: Springer International Publishing.

Nunnally, J.C. and Bernstein, I.H., 1994. Psychometric Theory. $3^{\text {rd }}$ ed. New York, NY: McGraw-Hill Book Company. 
Runar Edvardsson, I. and Durst, S., 2014. Outsourcing of knowledge processes: a literature review. Journal of Knowledge Management, [e-journal] 18(4), pp. 795-811. https://doi.org/10.1108/JKM-01-2014-0033.

Spender, J.C., 2014. Business strategy: Managing uncertainty, opportunity, \& enterprise. Oxford, U.K.: Oxford University Press.

Sumbal, M.S., Tsui, E., Cheong, R. and See-to, E.W.K., 2018. Critical areas of knowledge loss when employee leave in the oil industry. Journal of Knowledge Management, [e-journal] 22(7), pp.1573-1590. https://doi.org/10.1108/JKM-08-2017-0373.

Swart, J. and Harvey, P., 2011. Identifying knowledge boundaries: The case of networked projects. Journal of Knowledge Management, 15(5), pp. 703-721.

WCED, 1987. Our Common Future - The Brundtland Report. S.1: World Commission on Environment and Development.

Zieba, M. and Durst, S., 2018. Knowledge risks in the sharing economy. In: E.M. Vatamanescu and F. Pinzaru eds., 2018. Knowledge management sharing in the sharing Economy. Cham, Switzerland: Springer International Publishing, pp.253-270. 